\title{
Abnormal Fetal Attitude
}

National Cancer Institute

\section{Source}

National Cancer Institute. Abnormal Fetal Attitude. NCI Thesaurus. Code C92725.

An abnormality in the position of the fetus during the labor and delivery process. 